\title{
Terapi Antikoagulan pada Anak
}

Novie Amelia Chozie, Raisa Cecilia Sarita

Departemen Ilmu Kesehatan Anak Fakultas Kedokteran Universitas Indonesia/RSUP Dr Cipto Mangunkusumo, Jakarta

Seiring berkembangnya pengobatan dan teknologi di rumah sakit seperti pemasangan akses vaskular, serta kondisi penyakit pada anak, maka faktor risiko kejadian trombosis pada anak juga semakin meningkat. Kejadian trombosis ini perlu penanganan berupa terapi antikoagulan yang bertujuan untuk menurunkan risiko emboli, mencegah komplikasi, dan profilaksis bagi individu yang berisiko. Penggunaan antikoagulan pada anak di praktik klinis sehari-hari sebagian besar menggunakan data ekstrapolasi dari hasil studi pada orang dewasa. Terbatasnya data yang ada saat ini dan sistem hemostasis anak yang berbeda dengan dewasa menyebabkan penggunaan antikoagulan pada anak menjadi tantangan khusus. Beberapa pilihan terapi antikoagulan masing-masing memiliki kelebihan dan kekurangannya baik dari sisi pengaturan dosis, frekuensi pemberian, pemantauan, efikasi dan efek samping. Tinjauan pustaka ini akan membahas penggunaan antikoagulan pada anak khususnya heparin (unfractionated heparin, low molecular weight heparin), warfarin, dan perkembangan studi antikoagulan oral baru, serta pada populasi khusus yaitu anak dengan keganasan, sindrom lupus eritematosus, dan infeksi virus SARS-COV-2. Sari Pediatri 2021;23(3):205-14

Kata kunci: antikoagulan, anak, trombosis, heparin, warfarin

\section{Anticoagulant Therapy in Children}

\begin{abstract}
Novie Amelia Chozie ${ }^{1}$, Raisa Cecilia Sarita ${ }^{1}$
The development of treatment and technology such as vascular access devices in management of certain diseases and conditions in children leads to the increase of risk factors for thrombotic events in children. Thrombosis requires anticoagulant therapy in order to decrease the risk of embolism, prevent complications, and for thrombosis prophylaxis in individuals at risk. However, the use of anticoagulants in a pediatric settings mostly uses extrapolated data from adult studies. The lack of data available and the physiologic system of hemostasis in children present special challenges. Several anticoagulant therapies may have different advantages and disadvantages from dosing, frequency, monitoring, efficacy, and side effects. This review will mainly discuss the use of anticoagulant therapy in children including heparin (unfractionated heparin, low molecular weight heparin), warfarin, and the development of direct oral anticoagulants, as well as the use of anticoagulant therapy in specific children with malignancy, systemic lupus erythematosus, and SARS-COV-2 infection. Sari Pediatri 2021;23(3):205-14
\end{abstract}

Keywords: anticoagulant, children, thrombosis, heparin, warfarin

Alamat korespondensi: Novie Amelia Chozie. Departemen Ilmu Kesehatan Anak Fakultas Kedokteran Universitas Indonesia RSUP Dr Cipto Mangunkusumo, Jakarta. Email: novie.amelia@ui.ac.id 
S istem hemostasis neonatus dan anak berbeda dengan dewasa. Anak umumnya terlindungi dari kejadian trombosis karena adanya mekanisme khusus, seperti penurunan kapasitas untuk menghasilkan trombin, peningkatan kapasitas $\alpha 2$ makroglobulin untuk menginhibisi trombin, dan peningkatan potensi antitrombotik pada dinding pembuluh darah. ${ }^{1}$ Seiring dengan perkembangan kemajuan pengobatan dan teknologi di rumah sakit, faktor predisposisi atau faktor risiko terjadinya trombosis pada anak diperkirakan semakin meningkat, yaitu dengan penggunaan vascular access devices, anak dengan kelainan jantung bawaan, kanker, penyakit ginjal, infeksi, pasca transplantasi organ, inflamasi dan prematuritas. ${ }^{2}$ Kejadian tromboemboli pada anak dibagi menjadi tromboemboli vena (VTE) dan tromboemboli arteri.

\section{Tromboemboli Vena (VTE)}

Sejumlah kondisi yang berhubungan dengan peningkatan risiko VTE pada anak yang teridentifikasi berdasarkan studi meta-analisis, ${ }^{1}$ antara lain, riwayat rawat inap lebih dari 72 jam, kanker yang aktif, pemasangan akses vena sentral, terapi estrogen dalam 1 bulan terakhir, penyakit inflamasi sistemik (baru terdiagnosis, tidak terkontrol, atau kambuh), perawatan di ICU, penggunaan ventilasi mekanik, penurunan mobilisasi (Braden Q-score $<2$ ), obesitas (BMI>persentil $99^{\text {th }}$ terhadap usia), usia postpubertas, dehidrasi berat yang membutuhkan intervensi, pembedahan dengan durasi $>90$ menit dalam 14 hari terakhir, infeksi lokal berat atau infeksi sistemik (hasil dahak positif/kultur darah, atau penggunaan antibiotik empiris), trauma, penyakit jantung bawaan atau didapat dengan stasis vena atau kegagalan pembuluh darah vena balik, riwayat tromboemboli vena sebelumnya, dan riwayat keluarga derajat pertama dengan VTE sebelum usia 40 tahun atau tanpa pencetus. ${ }^{(1,3-5)} \mathrm{Gambar}$ 1 menunjukkan algoritma diagnosis dan tata laksana tromboemboli vena pada anak.

\section{Tromboemboli arteri}

Studi mengenai insidens tromboemboli arteri pada anak masih sangat terbatas. Umumnya, penyebab terjadinya tromboemboli arteri adalah pemasangan akses di pembuluh arteri, baik di femoral, umbilikal, maupun di perifer. ${ }^{1}$

\section{Pilihan obat antikoagulan untuk terapi pada anak}

Sebelum memulai terapi antikoagulan pada anak, perlu diketahui data berat badan pasien, pemeriksaan darah lengkap (DPL), international normalized ratio (INR), activated partial thromboplastin time (APTT), ureum, dan kreatinin. ${ }^{1}$ Beberapa hal yang harus diperhatikan pada anak yang menerima terapi antikoagulan, yaitu

- Hindari injeksi intramuskular dan pungsi arteri jika memungkinkan. Jika perlu, berikan tekanan eksternal dalam waktu lama (minimal 5 menit, tekanan kuat) untuk mengurangi perdarahan.

- Jika dibutuhkan obat anti nyeri, hindari golongan antiplatelet (ibuprofen). Lebih direkomendasikan penggunaan golongan acetaminophen (parasetamol).

- Jika warfarin akan diberikan jangka panjang (>12 bulan, contohnya pada kasus katup jantung mekanik), maka pemeriksaan densitas tulang dilakukan sebelum pemberian antikoagulan dan setiap 12 bulan berikutnya untuk menilai adanya osteoporosis.

- Edukasi sesuai usia harus diberikan kepada anak dan orang tua mengenai risiko antikoagulasi, manfaat, dan pemantauan yang terkait dengan terapi.

\section{Heparin \\ Unfractionated Heparin (UFH)}

\section{Mekanisme Kerja UFH}

UFH merupakan rantai mukopolisakarida yang memberikan efek antikoagulan dengan cara berikatan dan mempercepat kerja antithrombin III (ATIII) pada faktor koagulasi inaktif yaitu IIa (thrombin), Xa, IXa, Xia, dan XIIa. Dibandingkan dengan orang dewasa, anak memiliki kadar plasma antithrombin dan prothrombin yang lebih sedikit sehingga menghasilkan thrombin yang lebih sedikit. UFH diberikan secara intravena dan dieliminasi melalui ikatan reseptor sel endotelial dan makrofag. ${ }^{6,7}$ 


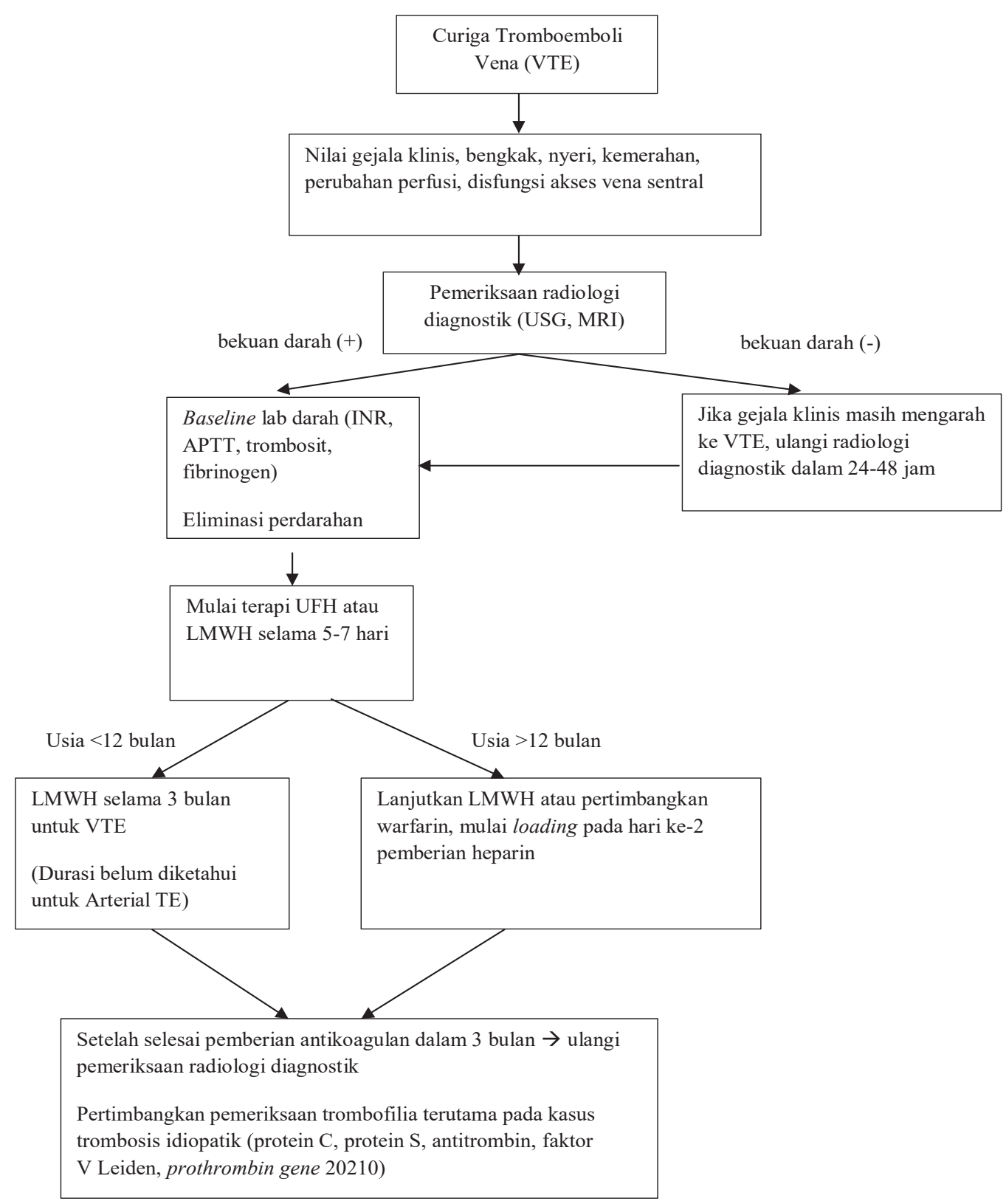

Gambar 1. Pendekatan diagnosis dan protokol tatalaksana pada tromboemboli vena sistemik (VTE). INR, international normalized ratio; LMWH, low-molecular weight heparin; APTT Activated partial thrombolastin time; TE, tromboemboli; $\mathrm{UFH}$, unfractionated heparin. (dikutip dengan modifikasi) ${ }^{1}$

\section{Rekomendasi dosis UFH pada anak}

Dosis UFH yang direkomendasikan untuk anak berdasarkan adaptasi dari dosis pada dewasa. Pemberian harus menggunakan jalur intravena khusus yang tidak digunakan untuk memasukkan terapi lain dengan tujuan untuk mempertahankan kadar konstan heparin. Pemantauan dasar penggunaan UFH adalah pemeriksaan darah lengkap, PT, dan APTT. Dosis awal, lanjutan, dan pemantauan UFH diuraikan pada Tabel (1)

\section{Komplikasi dan efek samping}

Komplikasi pemberian heparin yang dilaporkan dalam literatur, antara lain, perdarahan, osteoporosis, dan trombositopenia akibat heparin (Heparin-induced thrombocytopenia- HIT). Insidens perdarahan mayor 
Novie Amelia Chozie dkk: Terapi antikoagulan pada anak

Tabel 1. Dosis awal, dosis lanjutan, dan pemantauan UFH berdasarkan APTT atau anti-Xa ${ }^{1,6,8}$

\begin{tabular}{|c|c|c|c|}
\hline \multicolumn{2}{|c|}{$\begin{array}{l}\text { Dosis bolus (jika tidak berisiko } \\
\text { tinggi untuk perdarahan) }\end{array}$} & \multicolumn{2}{|l|}{75 unit $/ \mathrm{kg}$, diberikan intravena dalam 10 menit } \\
\hline \multirow{2}{*}{$\begin{array}{l}\text { Dosis awal } \\
\text { infus kontinyu }\end{array}$} & & \multicolumn{2}{|c|}{ Usia gestasi 28 minggu sampai 1 tahun: 28 unit $/ \mathrm{kg} / \mathrm{jam}$} \\
\hline & \multicolumn{3}{|c|}{ Usia $>1$ tahun: 20 unit $/ \mathrm{kg} / \mathrm{jam}$} \\
\hline APTT (detik) & Anti-Xa (unit/mL) & Pengaturan dosis & Pemantauan Lab \\
\hline$<50$ & $<0.1$ & $\begin{array}{l}\text { Berikan } 50 \text { unit/kg bolus dan tingkatkan laju } \\
\text { infusan sebanyak } 10 \%\end{array}$ & 4 jam setelah nilai berubah \\
\hline $50-59$ & $0.1-0.29$ & Tingkatkan laju infusan sebanyak $10 \%$ & 4 jam setelah nilai berubah \\
\hline $60-85$ & $0.3-0.7$ & Pertahankan laju infusan & 4 jam, dan dilanjutkan per 24 jam \\
\hline $86-95$ & $0.71-0.9$ & Penurunan laju infusan sebanyak $10 \%$ & 4 jam setelah nilai berubah \\
\hline $96-120$ & $0.91-1$ & $\begin{array}{l}\text { Pertahankan laju infusan selama } 30 \text { menit dan } \\
\text { penurunan laju infusan sebanyak } 10 \%\end{array}$ & 4 jam setelah nilai berubah \\
\hline$>120$ & $>1$ & $\begin{array}{l}\text { Pertahankan laju infusan selama } 60 \text { menit dan } \\
\text { penurunan laju infusan sebanyak } 15 \%\end{array}$ & 4 jam setelah nilai berubah \\
\hline
\end{tabular}

Ket: Evaluasi parameter APTT dan Anti-Xa pertama pada 4 jam setelah dosis bolus dan infus pertama). Hasil APTT 60-85 detik diasumsikan setara anti-Xa 0.3-0.7 unit/mL. CBC complete blood count, PT prothrombin time, APTT activated partial thromboplastin time, UFH unfractionated heparin

telah dilaporkan pada dua studi kohort prospektif., ${ }^{9}, 10$ Perdarahan adalah komplikasi tersering yang dijumpai dalam penggunaan antikoagulan, terutama pada neonatus. Dosis bolus harus digunakan dengan hatihati atau dihindari pada neonatus prematur karena kurangnya kapasitas untuk menghasilkan thrombin. Jika seorang pasien mengalami perdarahan berat, infus UFH harus segera dihentikan dan pemberian komponen darah dapat diberikan jika dibutuhkan. Efek antikoagulan UFH akan hilang dalam 4-6 jam namun antidotum berupa protamin sulfat dapat diberikan untuk menghentikan aktivitas antikoagulan UFH (efek reversal). Selain itu, penggunaan UFH jangka panjang dapat mengakibatkan kejadian osteoporosis pada anak. . $^{3,6,7}$

Efek samping lain yang dapat terjadi adalah terbentuknya antibodi terhadap kompleks heparin-PF4 pada permukaan trombosit atau dikenal sebagai heparin induced thrombocytopenia (HIT). Ikatan antibodi pada kompleks ini menyebabkan aktivasi trombosit dan keadaan pro-trombotik. ${ }^{11}$ Secara klasik, HIT ditandai dengan trombositopenia yang muncul 5-10 hari pasca pajanan heparin, dengan penurunan $50 \%$ dalam jumlah trombosit awal. Jika dicurigai HIT, maka semua heparin harus segera dihentikan. ${ }^{3,7}$ Dalam satu tinjauan pustaka sistematis, dilaporkan insidens HIT pada anak lebih rendah dari dewasa, yaitu 0,33\% kasus pada anak dan tidak ditemukan kasus pada neonatus. ${ }^{11}$

\section{Low Molecular Weight Heparin (LMWH)}

\section{Mekanisme kerja LMWH}

Low Molecular Weight Heparin merupakan turunan dari UFH, yang memiliki rantai polisakarida yang lebih pendek, serta bekerja dengan cara berikatan dan memicu aktivitas antikoagulan ATIII. 3,7 Pemberian LMWH secara injeksi subkutan dan disekresi via ginjal. Keuntungan LMWH, antara lain, pemantauan minimal karena bioavailibilitas yang baik dibandingkan dengan UFH. Contoh obat LMWH antara lain: enoxaparin, dalteparin, nadroparin, dan tinzaparin. Enoxaparin merupakan pilihan obat jenis LMWH yang umum dipakai. Puncak efek antikoagulan pada enoxaparin muncul dalam 4-6 jam setelah pemberian subkutan dan waktu paruhnya adalah 4.5-7 jam. ${ }^{6}$

\section{Rekomendasi dosis}

Rentang dosis terapeutik LMWH untuk anak mengikuti beberapa studi rujukan pada populasi dewasa. Kisaran efek terapeutik LMWH adalah kadar anti-Xa di antara 0,5-1 unit/mL. Pedoman American College of Chest Physicians (ACCP) merekomendasikan dosis awal enoxaparin adalah $1,5 \mathrm{mg} / \mathrm{kg}$ untuk neonatus, sedangkan beberapa studi melaporkan dosis awal yang lebih tinggi yaitu $1,7 \mathrm{mg} / \mathrm{kg}$. Dosis lengkap enoxaparin terlampir pada Tabel 2. 
Komplikasi perdarahan merupakan komplikasi tersering, diikuti dengan kejadian HIT dan osteoporosis. Osteoporosis lebih jarang terjadi dibandingkan UFH. Penyuntikan secara subkutan yang terus-menerus juga mengakibatkan nyeri dan hematoma sehingga dianjurkan untuk melakukan penggantian lokasi injeksi secara teratur. ${ }^{6}$

\section{Antagonis Vitamin K}

Contoh Antagonis vitamin K (VKA) adalah warfarin, acenocoumarol dan phenprocoumon. Jenis VKA oral yang paling umum digunakan pada populasi anak adalah warfarin. Pemberian warfarin pada neonatus dan bayi sebaiknya dilakukan secara hati-hati karena neonatus dan bayi yang mendapat ASI eksklusif biasanya mengalami defisiensi vitamin $\mathrm{K}$ karena rendahnya konsentrasi vitamin $\mathrm{K}$ pada ASI sehingga sangat sensitif terhadap VKA. ${ }^{1,6}$ Selain itu, bayi dan anak yang mendapatkan tambahan nutrisi formula akan resisten terhadap warfarin karena sediaan ini biasanya disuplementasi dengan tambahan vitamin $\mathrm{K}$. Tantangan yang terkait pengelolaan dan pemantauan terapi warfarin ini menyebabkan warfarin tidak direkomendasikan pada anak di bawah 12 bulan kecuali pada bayi dengan katup jantung mekanis. Mayoritas penggunaan warfarin pada anak adalah untuk profilaksis trombosis pada penyakit jantung, antara lain, prosedur bedah Fontan, katup prostetik, kardiomiopati dan penyakit Kawasaki. Warfarin bekerja dengan menghambat karboksilasi faktor pembekuan dependen vitamin $\mathrm{K}$ yang dibentuk oleh hati (II, VII, IX, X), protein C dan protein S. Absorpsi warfarin cepat dan berikatan dengan plasma protein seperti albumin, dan dicerna di hati melalui sistem sitokrom P450 dengan waktu eliminasi panjang sekitar 35-40 jam.,

Rekomendasi dosis

Pasien dengan trombosis akut sebaiknya diberikan UFH atau LMWH sebelum pemberian warfarin. Hal ini disebabkan sifat farmakokinetik warfarin yang membutuhkan 5-7 hari untuk mencapai efek terapeutik antikoagulan. Untuk mengatasi hal ini, warfarin perlu diberikan bersama golongan antikoagulan lain (misalnya UFH atau LMWH) secara bersamaan selama 3-5 hari hingga kadar INR mencapai efek terapeutik sebagai berikut $^{6}$

- Dosis inisial adalah $0.2 \mathrm{mg} / \mathrm{kgBB}$ (maksimal 10 mg-lihat tabel 3)

- Dosis dibulatkan hingga dosis sesuai dengan sediaan

- Lanjutkan UFH/LMWH dan warfarin hingga 5 hari

- Cek INR pada hari ke-5

- Jika INR adekuat, hentikan LMWH. Jika INR belum adekuat maka lanjutkan LMWH dan naikkan dosis warfarin (merujuk pada Tabel 3)

Tabel 2. Dosis awal dan penyesuaian dosis enoksaparin berdasarkan kadar anti Xa ${ }^{1,6,8}$

\begin{tabular}{|c|c|c|}
\hline $\begin{array}{l}\text { Dosis awal } \\
\text { enoxaparin }\end{array}$ & $\begin{array}{l}\text { Usia } \leq 2 \text { bulan: } 1,5 \mathrm{mg} / \mathrm{kg} \text { SK setiap } 12 \text { jam } \\
\text { Maksimum: } 3 \mathrm{mg} / \mathrm{kg} \text { SK setiap } 12 \text { jam }\end{array}$ & \\
\hline & $\begin{array}{l}\text { Usia } \geq 2 \text { bulan sampai } 18 \text { tahun: } 1 \mathrm{mg} / \mathrm{kg} \text { SK setiap } \\
12 \text { jam } \\
\text { Maksimum: } 2 \mathrm{mg} / \mathrm{kg} \text { SK setiap } 12 \text { jam }\end{array}$ & \\
\hline \multicolumn{3}{|c|}{ Dosis titrasi berdasarkan monitoring anti-Xa yang diambil 4 jam setelah pemberian dosis pertama. } \\
\hline Anti-Xa (unit/mL) & Pengaturan dosis & Pemantauan Lab \\
\hline$<0.35$ & $\begin{array}{l}\text { Berikan } 50 \text { unit/kg bolus dan tingkatkan laju infus } \\
10 \%\end{array}$ & 4 jam setelah dosis kedua \\
\hline $0,35-0,49$ & Tingkatkan laju infus $10 \%$ & 4 jam setelah dosis kedua \\
\hline $0,5-1$ & Pertahankan laju infus & Sekali seminggu 4 jam setelah dosis kedua \\
\hline $1,1-1,5$ & Penurunan laju infus $10 \%$ & 4 jam setelah dosis kedua \\
\hline $1,6-2$ & $\begin{array}{l}\text { Pertahankan laju infus selama } 30 \text { menit dan } \\
\text { penurunan laju infus } 10 \%\end{array}$ & 4 jam setelah dosis kedua \\
\hline$>2$ & $\begin{array}{l}\text { Pertahankan laju infus selama } 60 \text { menit dan } \\
\text { penurunan laju infus sebanyak } 15 \%\end{array}$ & $\begin{array}{l}\text { Setiap } 12 \text { jam sampai anti-Xa }<0,5 \text { unit } / \mathrm{mL} \text {, } \\
\text { selanjutnya } 4 \text { jam setelah dosis lanjutan }\end{array}$ \\
\hline
\end{tabular}


hingga mencapai kadar INR yang adekuat.

- Berdasarkan penelitian kohort terbesar yang dilakukan Streif $\mathrm{dkk}^{12}$ untuk mencapai target INR $2-3$, anak $<1$ tahun umumnya membutuhkan dosis $0,33 \mathrm{mg} / \mathrm{kgBB}$, sedangkan usia $>1$ tahun membutuhkan dosis $0,09 \mathrm{mg} / \mathrm{kgBB}$.

Rekomendasi target INR untuk terapi VTE adalah $2,5^{2-3}$ dan untuk anak dengan katup jantung mekanik adalah $3(2,5-3,5)$. Saat pasien mencapai kisaran INR terapeutik, maka pengecekan INR selanjutnya dilakukan sekali seminggu selama 2-3 minggu untuk pemantauan dan mengetahui kadar dosis dan INR yang stabil. Setelah dosis dan INR stabil tercapai, maka pemantauan INR dilakukan setiap 2 minggu. Jika tidak ada perubahan dosis yang dilakukan, maka pasien akan dipantau dalam periode waktu yang lebih panjang (setiap 3-4 minggu). Selain itu, pengecekan INR juga dilakukan jika ada perubahan pada pemilihan obat pasien, asupan nutrisi terutama vitamin K (jika pasien tidak dapat makan, misalnya), gejala mual dan diare, penggunaan antibiotik dan gangguan fungsi hati. ${ }^{6,7}$ Dosis warfarin dipengaruhi oleh faktor umur, obatobatan yang dikonsumsi, diet, dan genetik. Dokter perlu memberikan edukasi kepada orang tua dan anak terutama mengenai makanan yang dapat memengaruhi kerja warfarin.

\begin{abstract}
Komplikasi
Komplikasi terapi VKA adalah perdarahan dan osteoporosis. Pengobatan perdarahan yang diinduksi oleh VKA adalah pemberian plasma segar beku, dan konsentrat kompleks protrombin. Pemberian vitamin K belum terbukti sebagai pilihan terapi untuk efek reversal VKA pada perdarahan. ${ }^{6}$
\end{abstract}

\section{Antikoagulan oral baru (DOACS)}

Direct Oral Anticoagulants (DOACS) adalah molekul kecil yang dirancang untuk menghambat faktor koagulasi secara selektif dan spesifik dalam jalur koagulasi. ${ }^{14}$ DOACS dibagi menjadi penghambat langsung (dabigatran) dan penghambat faktor Xa (rivaroxaban, apixaban, endoxaban). Saat ini, DOACS sudah dipakai pada populasi dewasa untuk kasus trombosis dan dilaporkan menjadi pilihan tatalaksana yang efisien. ${ }^{14}$ Keuntungan yang dimiliki DOACS sangat sesuai dengan populasi anak, antara lain, administrasi via oral, efek farmakologi yang cepat, interaksi minimal dengan makanan dan obat, serta kemungkinan tidak diperlukannya pemantauan rutin. Pada laporan interim uji klinis acak terbuka fase III dabigatran (studi DIVERSITY) ditemukan bahwa penggunaan dabigatran hampir sama secara keamanan

Tabel 3. Dosis awal dan pemeliharaan warfarin pada anak $>10 \mathrm{~kg}^{6}$

\begin{tabular}{ll}
\hline INR & Langkah \\
\hline Inisiasi warfarin & \\
Hari-1 (jika baseline INR $<1,3)$ & Dosis loading* $0,2 \mathrm{mg} / \mathrm{kg} \times 1$, dosis maksimal $10 \mathrm{mg}^{2,6,8,13}$ \\
Hari 2-4 & Ulangi dosis loading awal \\
INR $1,1-1,3$ & $50 \%$ dari dosis loading awal \\
INR $1,4-1,9$ & $50 \%$ dari dosis loading awal \\
INR 2-3 & $25 \%$ dari dosis loading awal \\
INR 3,1-3,5 & Stop obat hingga INR $<3.5$ lalu ulangi $50 \%$ dari dosis sebelumnya \\
INR $>3,5$ & \\
Dosis pemeliharaan & Naikkan dosis $20 \%$ \\
INR 1,1-INR 1,3 & Naikkan dosis $10 \%$ \\
INR 1,4-1,9 & Tidak ada perubahan \\
INR 2-3 & Turunkan dosis 20\% \\
INR 3,1-3,5 & Pertahankan hingga INR $<3.5$ lalu ulangi $50 \%$ dari dosis sebelumnya \\
INR $>3,5$ & *Pada anak dengan gangguan fungsi hati atau pasca prosedur Fontan, dosis inisial warfarin $0,1 \mathrm{mg} / \mathrm{kg}$, dosis tunggal per hari
\end{tabular}


dan efikasi dibandingkan dengan antikoagulan lain yang telah digunakan pada anak. Sejumlah uji klinis terbuka juga memberikan data fase I dan II yang menjanjikan, menunjukkan bahwa DOACS memiliki hubungan farmakokinetik dan farmakodinamik yang konsisten dan menunjukkan kemanjuran dan keamanan yang sebanding dengan LMWH dan VKA., ${ }^{75}$

\section{Penghentian obat-obatan antikoagulan}

Obat antikoagulan dapat dihentikan berdasarkan indikasi penyakit ataupun kondisi pasien, antara lain, selesainya durasi pengobatan, tercapainya INR yang melebihi target (Tabel 3), komplikasi perdarahan, dan persiapan sebelum tindakan/operasi. Terapi antikoagulan pada pengobatan VTE umumnya dihentikan setelah 3 bulan lalu dilanjutkan dengan evaluasi radiologi diagnostik dan pemeriksaan penunjang (Gambar 1). Pada kasus komplikasi perdarahan yang mengancam jiwa, penghentian terapi antikoagulan harus segera dilakukan. Penghentian obat seperti LMWH dan UFH diikuti dengan pemberian antidotum yaitu protamin sulfat, sedangkan pada golongan VKA (warfarin), dapat diberikan faktor prothrombin kompleks/ activated prothrombin complex concentrates (aPCCs) atau transfusi FFP. ${ }^{8,16}$ Untuk manajemen perioperatif, durasi penghentian terapi antikoagulan bergantung pada status individual masing-masing pasien yang dipengaruhi oleh risiko perdarahan maupun tromboemboli serta tindakan operasi apa yang akan dilakukan. Sampai saat ini, protokol pada anak masih mengikuti protokol dari studi dewasa. ${ }^{17}$

\section{Penggunaan antikoagulan pada populasi khusus}

\author{
Antikoagulan pada anak dengan kanker \\ Antikoagulan utama LMWH merupakan pilihan \\ untuk anak dengan kanker yang membutuhkan \\ obat antikoagulan. Trombositopenia berulang akibat \\ kemoterapi menyebabkan perlu modifikasi tatalaksana \\ antikoagulan akibat risiko perdarahan yang meningkat. \\ Prediksi waktu trombositopenia dan frekuensi \\ pemantauan laboratorium darah yang tepat merupakan \\ salah satu komponen penting. Salah satu strategi yang \\ digunakan adalah jika trombosit 50.000/ $\mathrm{L}$, maka \\ dosis antikoagulan diturunkan menjadi setengahnya
}

dan ketika jumlah trombosit di bawah 30.000/ $\mu \mathrm{L}$ maka antikoagulan seharusnya dihentikan. Namun, praktik ini belum didukung oleh bukti studi yang kuat. ${ }^{2}$ Selain itu, pada anak dengan leukemia, prosedur pungsi lumbal untuk kemoterapi intratekal dapat meningkatkan risiko perdarahan sehingga rekomendasi yang diberikan adalah menghentikan dua dosis LMWH sebelum tindakan, walaupun rekomendasi ini hanya berdasarkan satu studi kecil yang menilai residual anti-Xa aktivitas setelah pemberian dosis LMWH pada anak ${ }^{2}$

\section{Antikoagulan untuk trombosis pada SLE}

Trombosis arteri dan/atau vena merupakan salah satu gejala klinis pada penderita SLE dengan prevalensi $>10 \%$. Pada studi uji acak klinis Finazzi $\mathrm{dkk}^{18}$ dan Crowther $\mathrm{dkk}^{19}$ menyarankan target INR 2.0-3.0 untuk mencegah rekurensi trombosis pada pasien dewasa dengan sindrom antifosfolipid tanpa komplikasi yang mengalami trombosis vena atau arteri. Saat ini uji klinis untuk menetapkan target INR yang optimal pada anak belum dilakukan. Studi kohort oleh Manco-Johnson $\mathrm{dkk}^{20}$ mendapatkan tidak ada kasus trombosis berulang pada populasi kohort yang anak yang menggunakan antikoagulan oral selama periode 3 bulan hingga 7 tahun dengan target INR 2,0-3,0.

Durasi pemberian antikoagulan ditentukan berdasarkan keadaan individu pasien seperti adanya Antiphospolipid antibody (APLA), lokasi trombosis, kekambuhan (dinilai dari kenaikan D-dimer), dan adanya faktor pencetus. Terapi antikoagulan jangka panjang biasanya dibutuhkan pada keadaan trombosis spontan, trombosis arteri dan adanya APLA yang terus positif. Durasi terapi antikoagulan direkomendasikan $A C C P$ selama 3 bulan. Uji acak klinis Kids-DOTT (https:// clinicaltrials.gov/ct2/show/study/NCT00687882) yang membandingkan efektivitas pemberian antikoagulan selama 6 minggu dengan 3 bulan masih berjalan hingga Desember 2021. Data terakhir menunjukkan sebanyak 3.3\% dan 1,4\% kasus trombosis kambuh dan perdarahan terjadi pada kelompok 6 minggu dan 3 bulan. ${ }^{21}$ Dengan tidak adanya uji klinis berskala besar pada anak, rekomendasi untuk durasi antikoagulasi pada anak dengan trombosis berasal dari data penggunaan pada populasi dewasa.

\section{Antikoagulan pada kasus anak dengan infeksi SARS- CoV-2 (COVID 19)}

Banyak laporan kasus pada orang dewasa yang terinfeksi virus SARS-CoV-2 (COVID 19) dengan gejala klinis 
berat terjadi peningkatan risiko koagulasi intravaskular diseminata dan tromboemboli vena. Hal ini ditandai dengan parameter uji hemostasis yang abnormal, yaitu peningkatan fibrinogen dan D-dimer yang berkorelasi dengan penanda inflamasi akut seperti $C$-reactive protein, disertai dengan pemanjangan $\mathrm{PT}$, trombositopenia ringan, dan APTT normal atau sedikit meningkat. Peningkatan D-dimer dari waktu ke waktu menandakan meningkatnya proses koagulasi dan fibrinolisis dan berkaitan dengan peningkatan mortalitas pada orang dewasa.

Sebuah studi pada 449 pasien dewasa dengan infeksi berat menunjukkan angka kematian lebih rendah pada mereka yang menerima terapi antikoagulan. ${ }^{22}$ Oleh karena itu, salah satu rekomendasi untuk pencegahan dan pengelolaan gangguan koagulasi akibat infeksi COVID19 pada orang dewasa adalah pemberian heparin berat molekul rendah, terutama dalam kasus ARDS. ${ }^{23,24}$ Italian Society of Pediatric Infectious Diseases dan Italian Society of Pediatrics menyarankan untuk tidak memberikan profilaksis secara rutin pada anak dengan infeksi COVID 19, mengingat insidens trombosis secara umum pada anak jauh lebih kecil dibandingkan orang dewasa. Untuk kelompok usia neonatus dan remaja yang merupakan golongan usia dengan insiden trombosis relatif lebih tinggi, kondisi inflamasi yang parah dapat mencetuskan aktivasi koagulasi dan karena itu terapi profilaksis dapat dipertimbangkan. Pengobatan yang disarankan adalah dengan enoxaparin subkutan 100-200 U/kg/hari, yang dapat ditingkatkan menjadi $150-300 \mathrm{U} / \mathrm{kg} / \mathrm{hari}$ pada neonatus. ${ }^{25}$

Berdasarkan konsensus ahli, Pediatric/Neonatal Hemostasis and Thrombosis Subcommittee of the International Society of Thrombosis and Hemostasis SSC menyarankan pemberian heparin berat molekul rendah dosis rendah secara subkutan dua kali sehari sebagai antikoagulan tromboprofilaksis (jika tidak terdapat kontraindikasi) pada anak yang dirawat dengan COVID 19 berat (termasuk sindrom inflamasi multisistem yang berat atau MIS-C) dan terdapat peningkatan kadar D-dimer yang signifikan atau pada anak yang memiliki faktor risiko VTE lainnya. Untuk anak-anak yang secara klinis tidak stabil atau mengalami gangguan ginjal berat, disarankan penggunaan UFH sebagai antikoagulan tromboprofilaksis. ${ }^{26}$

Loi $\mathrm{dkk}^{27}$ yang tergabung dalam Multidisciplinary Scientific Advisory Committee Children Hospital
Colorado and University of Colorado menyarankan pentingnya melakukan penilaian risiko untuk menentukan perlu tidaknya profilaksis antikoagulan pada anak dengan Covid 19 pada awal perawatan dan evaluasi berkala setiap hari.

Pemeriksaan laboratorium yang dianjurkan adalah darah tepi lengkap, fibrinogen, prothrombin time, D-dimer pada saat masuk dan diulang secara berkala. Peningkatan D-dimer dan derajat koagulasi intravaskular diseminata (KID) dapat merupakan indikasi perburukan klinis penyakitnya. Pemeriksaan radiologis untuk membuktikan adanya trombosis dilakukan hanya atas indikasi dengan memperhatikan aspek ketersediaan sarana di masing-masing rumah sakit. Pasien anak dengan faktor risiko trombosis direkomendasikan untuk mendapat terapi profilaksis antikoagulan baik dengan obat maupun secara mekanik (sesuai indikasi). Obat antikoagulan yang disarankan untuk profilaksis adalah LMWH atau UFH. Antikoagulan terapeutik disarankan untuk anak dalam terapi antikoagulan sebelumnya dan pada anak dengan kecurigaan atau terbukti VTE. Obat golongan DOACS tidak direkomendasikan karena terbatasnya data keamanan pada anak dan dewasa dengan COVID 19. Terapi trombolitik dapat dipertimbangkan untuk pasien dengan emboli paru atau limb-threatening DVT. Terapi trombolitik perlu dilakukan dengan koordinasi multidisiplin dari bidang hematologi, ERIA dan bidang terkait lainnya. ${ }^{27}$

Mengingat infeksi SARS CoV 2 merupakan penyakit yang relatif "baru" maka masih dibutuhkan data lebih lanjut untuk membuat rekomendasi di masa depan.

\section{Kesimpulan}

Penggunaan antikoagulan pada anak masih menjadi tantangan karena rekomendasi untuk dosis, pemantauan, durasi, dan intensitas masih didasarkan pada hasil penelitian orang dewasa. Dokter anak seyogyanya mampu menyesuaikan penilaian klinis untuk mempertimbangkan bukti yang tersedia dan memberikan terapi antikoagulan secara aman. Studi lebih lanjut perlu dilakukan untuk mengoptimalkan penggunaan antikoagulan pada anak dan meminimalkan efek samping. 
Novie Amelia Chozie dkk: Terapi antikoagulan pada anak

Tabel 4. Ringkasan rekomendasi klinis berbasis konsensus tentang penggunaan antikoagulan tromboprofilaksis pada pasien anak yang dirawat karena penyakit terkait COVID-19 dan anak yang dirawat tanpa gejala pada infeksi SARS-CoV2 ${ }^{23}$

\begin{tabular}{|c|c|c|c|}
\hline Situasi & $\begin{array}{l}\text { D-Dimer }>5 x \text { dari batas atas } \\
\text { nilai normal }\end{array}$ & $\begin{array}{l}\text { Faktor risiko Non-COVID } \\
19 \text { terkait HA-VTE* }\end{array}$ & $\begin{array}{l}\text { Rekomendasi antikoagulan } \\
\text { tromboprofilaksis }\end{array}$ \\
\hline \multirow{3}{*}{$\begin{array}{l}\text { Dirawat karena penyakit yang } \\
\text { berhubungan dengan COVID-19 } \\
\text { (termasuk MIS-C) }\end{array}$} & $\mathrm{Ya}$ & N/A & Ya \\
\hline & Tidak & Satu atau lebih & Ya \\
\hline & & Tidak ada & Tidak \\
\hline \multirow{2}{*}{$\begin{array}{l}\text { Dirawat dengan infeksi SARS- } \\
\text { Cov- } 2 \text { tanpa gejala }\end{array}$} & N/A & Beberapa & Ya \\
\hline & & Sedikit/tidak ada & Tidak \\
\hline
\end{tabular}

\section{Daftar pustaka}

1. Bauman M, Massicotte MP. Thromboembolic complications in children. Dalam: Arceci RJ, Hann IM, Smith OP, penyunting. Pediatric hematology. Edisi ke-3. Massachusetts: John Wiley and Sons; 2007.h.672-86.

2. Hepponstall M, Chan A, Monagle P. Anticoagulation therapy in neonates, children and adolescents. Blood Cells, Mol Dis 2017;67:41-7.

3. Newall F, Branchford B, Male C. Anticoagulant prophylaxis and therapy in children: current challenges and emerging issues. J Thromb Haemost 2018;16:196-208.

4. Mahajerin A, Branchford BR, Amankwah EK, dkk. Hospitalassociated venous thromboembolism in pediatrics: a systematic review and meta-analysis of risk factors and risk-assessment models. Haematologica 2015;100:1045-50.

5. Branchford BR, Mahajerin A, Raffini L, dkk. Recommendations for standardized risk factor definitions in pediatric hospitalacquired venous thromboembolism to inform future prevention trials: communication from the SSC of the ISTH. J Thromb Haemost 2017;15:2274-8.

6. Law C, Raffini L. A guide to the use of anticoagulant drugs in children. Pediatr Drugs 2015;17:105-14.

7. Monagle P, Newall F. Anticoagulation in children. Thromb Res 2012;130:142-6.

8. Monagle P, Chan AKC, Goldenberg NA, dkk. Antithrombotic therapy in neonates and children: Antithrombotic therapy and prevention of thrombosis. Edisi ke-9. American College of Chest Physicians Evidence-Based Clinical Practice Guidelines. Chest 2012;141(2 Suppl):e737S-e801S.

9. Andrew M, Marzinotto V, Brooker LA, dkk. Oral anticoagulation therapy in pediatric patients: a prospective study. Thromb Haemost 1994;71:265-9.

10. Kuhle S, Eulmesekian P, Kavanagh B, Massicotte P, Vegh P, Mitchell LG. A clinically significant incidence of bleeding in critically ill children receiving therapeutic doses of unfractionated heparin: a prospective cohort study. Haematologica 2007;92:244-7.
11. Avila ML, Shah V, Brandao LR. Systematic review on heparininduced thrombocytopenia in children: a call to action. J Thromb Haemost 2013;11:660-9.

12. Streif W, Andrew M, Marzinotto V, dkk. Analysis of warfarin therapy in pediatric patients: A prospective cohort study of 319 patients. Blood 1999;94:3007-14.

13. Schapkaitz E, Sherman GG, Jacobson BF, dkk. Paediatric anticoagulation guidelines. South African Med J 2012;102:171-5.

14. Male C, Thom K, O’Brien SH. Direct oral anticoagulants: What will be their role in children? Thromb Res 2019;173:178-85.

15. Albisetti M. Use of direct oral anticoagulants in children and adolescents. Hamostaseologie 2020;40:64-73.

16. Witt DM, Nieuwlaat R, Clark NP, dkk. American Society of Hematology 2018 guidelines for management of venous thromboembolism: optimal management of anticoagulation therapy. Blood Adv 2018;2:3257-91.

17. Polania Gutierrez JJ, Rocuts KR. Perioperative anticoagulation management. Dalam: StatPearls. Treasure Island (FL): StatPearls Publishing; 2021.

18. Finazzi G, Brancaccio V, Schinco P, dkk. A randomized clinical trial of high-intensity warfarin vs. conventional antithrombotic therapy for the prevention of recurrent thrombosis in patients with the antiphospholipid syndrome (WAPS). J Thromb Haemost 2005;3:848-53.

19. Crowther MA, Ginsberg JS, Julian J, dkk. A comparison of two intensities of warfarin for the prevention of recurrent thrombosis in patients with the antiphospholipid antibody syndrome. N Engl J Med 2003;349:1133-8.

20. Manco-Johnson MJ, Nuss R. Lupus anticoagulant in children with thrombosis. Am J Hematol 1995;48:240-3.

21. Goldenberg NA, Abshire T, Blatchford PJ, dkk. Multicenter randomized controlled trial on Duration of Therapy for Thrombosis in Children and Young Adults (the Kids-DOTT trial): pilot/feasibility phase findings. J Thromb Haemost 2015;13:1597-605.

22. Tang N, Bai H, Chen X, Gong J, Li D, Sun Z. Anticoagulant treatment is associated with decreased mortality in severe coronavirus disease 2019 patients with coagulopathy. J 
Thromb Haemost 2020;18:1094-9.

23. World Health Organization. Clinical management of severe acute respiratory infection (SARI) when COVID-19 disease is suspected: interim guidance. Geneva PP - Geneva: World Health Organization. Diakses pada 10Oktober 2021. Didapat dari: https://apps.who.int/iris/handle/10665/331446.

24. Thachil J, Tang N, Gando S, dkk. ISTH interim guidance on recognition and management of coagulopathy in COVID-19. J Thromb Haemost 2020;18:1023-6.

25. Venturini E, Montagnani C, Garazzino S, dkk. Treatment of children with COVID-19: position paper of the Italian Society of Pediatric Infectious Disease. Ital J Pediatr 2020;46:139.

26. Goldenberg NA, Sochet A, Albisetti M, dkk. Consensus-based clinical recommendations and research priorities for anticoagulant thromboprophylaxis in children hospitalized for COVID-19related illness. J Thromb Haemost 2020;18:3099-105.

27. Loi M, Branchford B, Kim J, Self C, Nuss R. COVID-19 anticoagulation recommendations in children. Pediatr Blood Cancer 2020;67:e28485. 